Trinity College

Trinity College Digital Repository

Faculty Scholarship

2008

Invertebrate Diet of Breeding and Nonbreeding Crested Caracaras (Caracara cheriway) in Florida

Joan L. Morrison

Trinity College, joan.morrison@trincoll.edu

Kyle E. Pias

Trinity College

J. Abrams

I. G. W. Gottlieb

M. Deyrup

See next page for additional authors

Follow this and additional works at: https://digitalrepository.trincoll.edu/facpub

Part of the Biology Commons 


\section{Authors}

Joan L. Morrison, Kyle E. Pias, J. Abrams, I. G. W. Gottlieb, M. Deyrup, and Michael McMillian 


\title{
INVERTEBRATE DIET OF BREEDING AND NONBREEDING CRESTED CARACARAS (CARACARA CHERIWAY) IN FLORIDA
}

\author{
JOAN L. MORRISON ${ }^{1}$ \\ MacAthur Agro-Ecology Research Center, 300 Buck Island Ranch Road, Lake Placid, FL 33852 U.S.A. \\ and Department of Biology, Trinity College, 300 Summit Street, Hartford, CT 06106 U.S.A. \\ Kule E. Plas, Jeffrey Abrams and Isabel G.W. Gottlieb \\ Department of Biology, Trinity College, 300 Summit Street, Hartford, CT 06106 U.S.A. \\ MARK DEYRUP \\ Archbold Biological Station, P.O. Box 2057, Lake Placid, FL 33862 U.S.A. \\ MiCHAEL MCMiLLIAN \\ MacArthur Agro-Ecology Research Center, 300 Buck Island Ranch Road, Lake Placid, FL 33852 U.S.A.
}

\begin{abstract}
We compared the invertebrate component of the diet of breeding and nonbreeding northern Crested Caracaras (Caracara cheriway) during the breeding season, January through April, in Florida, using pellet analysis. Pellets from breeding adults were collected at active nests and pellets of nonbreeding caracaras were collected from beneath a communal roost. During the breeding season, breeding and nonbreeding caracaras consumed invertebrate prey from a minimum of 61 genera and a total of 33 families from eight orders. Nonbreeding caracaras consumed greater total numbers of invertebrates, more different prey types, and a greater diversity of invertebrates than did breeding caracaras. Pellets of nonbreeding caracaras contained more invertebrates per pellet, and carrion insects occurred more frequently in pellets of nonbreeding caracaras. Our findings suggest hypotheses regarding the possible role of intraspecific competition in the use of particular habitats and food resources by breeding and nonbreeding caracaras in Florida. Breeding pairs of caracaras are highly territorial and primarily feed nestlings larger-sized vertebrate prey, and field observations indicated that territorial adults can exclude young (nonbreeding) birds from their breeding areas; thus, diet differences may reflect social structure within this population. If pairs of breeding adults exclude conspecifics from important food resources or foraging habitats, nonbreeders may hunt arthropods or rely on carrion by necessity, especially if nonbreeders occur in suboptimal habitat in which other prey are less available.
\end{abstract}

KEY WORDS: Crested Caracara, Caracara cheriway; communal roost; diet breadth; Florida, foraging, invertebrate, pellet analysis, territoriality.

\section{DIETA DE INVERTEBRADOS DE INDIVIDUOS REPRODUCTIVOS Y NO REPRODUCTIVOS DE CARA- CARA CHERIWAY EN FLORIDA}

RESUMEN.-Mediante el análisis de egagrópilas comparamos el componente de invertebrados en la dieta de individuos reproductivos y no reproductivos de Caracara cheriway de poblaciones norteñas de Florida, durante la época reproductiva, desde enero a abril. Colectamos egagrópilas de adultos reproductivos en nidos activos y egagrópilas de individuos no reproductivos debajo de un sitio comunitario de reposo. Durante la estación reproductiva, los individuos reproductivos y no reproductivos consumieron presas de invertebrados de un mínimo de 61 géneros y un total de 33 familias pertenecientes a ocho órdenes. Los individuos no reproductivos consumieron mayores números totales de invertebrados, más tipos diferentes de presas y una mayor diversidad de invertebrados que los individuos reproductivos. Las egagrópilas de los individuos no reproductivos contuvieron más invertebrados por egagrópila y presentaron insectos carroñeros con mayor frecuencia. Nuestros resultados plantean la hipótesis del posible papel de la compe-

\footnotetext{
1 Email address: joan.morrison@trincoll.edu
} 
tencia intraespecífica en el uso de ambientes particulares y de recursos alimenticios por parte de individuos reproductivos y no reproductivos en Florida. Las parejas reproductivas de $C$. cheriway son muy territoriales y alimentan a los pichones principalmente con vertebrados de mayor tamaño. Las observaciones de campo indicaron además que los adultos territoriales pueden excluir a aves juveniles (no reproductivas) de sus áreas de cría; por ende, las diferencias en la dieta pueden reflejar la estructura social en esta población. Si las parejas de adultos reproductivos impiden a aves coespecíficas el acceso a recursos alimenticios importantes y a ambientes de forrajeo, los individuos no reproductivos podrian estar cazando artrópodos o utilizando carroña por necesidad, especialmente si estos últimos se encuentran en ambientes subóptimos donde otras presas son menos disponibles.

[Traducción del equipo editorial]

Studies of avian diet can provide information about a species' foraging ecology (e.g., ecological relationships between a species, its prey, and its habitats). Diet composition may be influenced by prey availability and breeding or social status of the predator (Goss-Custard and Durrell 1983, Hogstad 1991, Sol et al. 2000), and identification of prey types can aid in making inferences about habitats used for foraging. Within a species, feeding behavior may vary by sex, age, habitat, and season (Peters and Grubb 1983, Beeston et al. 2005), with important consequences for population structure. Particularly while breeding, adults may adjust their foraging behavior, habitat, or prey selection to compensate for the increased daily energetic requirements of reproduction (Newton 1979, Barrows 1987).

The northern Crested Caracara (Caracara cheriway) is a dietary opportunist that feeds on carrion and a variety of live prey, including insects (Richmond 1976, Layne et al. 1977, Whitacre et al. 1982, Morrison et al. 2007). This unique member of the falcon family inhabits the southern United States and parts of Mexico and Central and South America (Morrison 1996, Dove and Banks 1999). Although studies have quantified aspects of the breeding-season diet of this raptor (Rodríguez-Estrella and Rivera-Rodríguez 1997, Morrison and Pias 2006) and its congener, the Southern Caracara ( $C$. plancus, Travaini et al. 2001), little comparative information, for example, among seasons, age classes, or between sexes, is available. Vargas et al. (2007) reported on diet throughout the annual cycle of the Southern Caracara in Argentina, but data represented pellets collected from only five breeding pairs. Morrison et al. (2007) reported a wide variety of insects and spiders in pellets collected at a roost of nonbreeding northern Crested Caracaras in Florida but focused on the birds' exposure to noxious chemicals as a result of this ingestion. In this study, we investigate the foraging ecology of breeding and nonbreeding northern Crested Caracaras, hereafter 'caracara,' during the breeding season in Florida by comparing the invertebrate diet of these two groups.

\section{METHODS}

We studied the diet of caracaras throughout their breeding range in south-central Florida where this species occurs as an isolated population and is threatened by widespread habitat loss (Morrison and Humphrey 2001). The landscape in this region is a mosaic of habitats that reflects complex patterns of land ownership and uses; principal land uses on private lands include cattle grazing, citrus, sugar cane, and other agricultural production. Lands in public ownership are managed primarily as natural habitats to support native plant and animal communities (Morrison and Humphrey 2001). Caracaras breed throughout this region, nesting and foraging primarily in pasture and other grassland habitats containing seasonally flooded wetlands and ditches (Morrison and Humphrey 2001). Nonbreeding caracaras range widely in south-central Florida and exploit similar habitats for foraging and roosting. Large communal roosts containing over 100 caracaras of all ages have been recorded (J. Dwyer and J. Morrison unpubl. data). Caracaras in Florida consume a wide variety of live prey, and over half of all vertebrate prey items identified at active nests represented species that use wetlands during all or part of their life history (Morrison and Pias 2006). Carrion composes approximately $33 \%$ of the diet of nesting caracaras in Florida (Morrison and Pias 2006).

To assess the invertebrate component of the diet of breeding and nonbreeding caracaras, we used pellet analysis (Marti 1987). We collected pellets at active nests throughout the species' currently known breeding range in Florida (Morrison and Pias 2006). For comparisons we selected 120 pellets that represented the diet of breeding adults at 52 different breeding areas and were approximately evenly distributed across January through April 
1994 through 1997. We believe these pellets represented the diet of breeding adults because during these months, the peak of the caracara's nesting season in Florida, most nests contained eggs or small nestlings. During the caracara's nesting season, prey fed to nestlings consisted primarily of larger vertebrate prey, not invertebrates (Travaini et al. 2001, Morrison and Pias 2006).

We collected pellets monthly during January through April 1999 from underneath a communal roost at the MacArthur Agro-Ecology Research Center (MAERC, $27^{\circ} 10^{\prime} \mathrm{N}, 81^{\circ} 12^{\prime} \mathrm{W}$ ), a division of Archbold Biological Station, near Lake Placid, FL. The roost was a group of $>10$ cabbage palms located in an actively grazed pasture. The majority of caracaras at communal roosts are young birds (age 1-3 yr) and most likely are nonbreeders ( $\mathrm{J}$. Dwyer unpubl. data). We observed only caracaras at this roost, so we assumed pellets collected at the roost represent the diet of an unknown number of nonbreeding caracaras during this period. For diet comparisons, we used 25 pellets sampled randomly from each larger monthly collection, totalling 100 pellets.

Pellets remained frozen after collection until they were analyzed; broken or degraded pellets were excluded from analysis. Pellets were air dried then dissected, and all diagnostic invertebrate pieces (heads, elytra, pronotum, and chelicerae) were collected. We identified each invertebrate prey type to the finest taxonomic level possible using the reference collection at Archbold Biological Station and other guides (Dillon and Dillon 1972, White 1983, Bug Guide 2007). The number of individuals of each prey type in each pellet was determined by counting the lowest number of possible individuals from the identified pieces. For example, three heads, two pronota, and four elytra of the same invertebrate type would be counted as three individuals. To describe the matrix material of each pellet, we spread the remaining portions of the pellet evenly on a gridded surface and visually estimated percent plant material using six categories $(0-5 \%$, 5-25\%, 25-50\%, 50-75\%, 75-95\%, and 95-100\%); category midpoints were used for analyses according to Daubenmire (1959). We compared mean numbers of invertebrates in pellets containing up to $25 \%$ plant material and in pellets containing $75-100 \%$ plant material, for nonbreeders and breeders, separately, using $t$ tests.

To facilitate diet comparisons, we expressed results for each prey type as percentage of total invertebrate prey and frequency of occurrence within the total number of pellets. We calculated Levins' diversity index (Levins 1968) at both the family and genus level as FNB $=1 / \Sigma p_{i}{ }^{2}$, where $p_{i}$ is the proportion of each prey type $i$ in the sample. We also calculated a standardized Levins' index following Colwell and Futuyma (1971) as FNBst $=($ FNB -1$) /(n-1)$ where $n$ is the total number of prey types consumed. This index allows comparisons among samples with different numbers of prey types; values approaching one indicate relatively more equitable use of prey (Colwell and Futuyma 1971). Finally, we compared diet similarity at the family and genus level between breeding and nonbreeding caracaras using Pianka's overlap index (Pianka 1973, Marti 1987):

$\mathrm{O}=\sum p_{i j} p_{i k} / \sqrt{\sum p_{i j}^{2} p_{i k}^{2}}$ where $p_{i j}$ and $p_{i k}$ are the proportions of the taxon $i$ for ejther breeders $(j)$ or nonbreeders $(k)$, respectively. Values of $O$ range from 0 with no overlap, to I for complete overlap.

\section{RESULTS}

During January-April in Florida, breeding and nonbreeding caracaras consumed invertebrate prey from a minimum of 61 genera and a total of 33 families from eight orders, primarily Coleoptera (Appendix). These invertebrates derive from four general ecological niches: dung, terrestrial (grassland or woodland), carrion, and aquatic (Morrison et al. 2007). Diet of breeders and nonbreeders overlapped more strongly at the family level $(70 \%)$ than at the genus level (52\%). Nonbreeding caracaras consumed greater total numbers of invertebrates, more different prey types, and a greater diversity of invertebrates at the genus level than breeding caracaras (Table 1). Pellets of nonbreeding caracaras contained more invertebrates per pellet $(t=-1.64, P$ $=0.05)$ and proportionally more Coleoptera $(Z=$ $10.56, P<0.01)$, primarily of the families Scarabaeidae, Carabidae, and Curculionidae, than pellets of breeding caracaras (Table 1 ). Carrion insects composed a larger percentage of the overall invertebrate prey consumed by breeding caracaras $(Z=8.55, P<$ 0.01 ), primarily because a few pellets contained large numbers of carrion beetles, mostly belonging to the family Silphidae. Carrion insects occurred more frequently in pellets of nonbreeding caracaras $(Z=$ 3.46, $P<0.01$, Fig. 1). Terrestrial $(Z=2.30, P<$ $0.01)$ and dung $(Z=2.38, P<0.01)$ invertebrates also occurred more frequently in pellets of nonbreeding caracaras (Fig. 1). All pellets contained the heads of countless numbers of fire ants (Solenopsis invicta); these were not included in analyses. 
Table 1. Nonbreeding caracaras (Caracara cheriway) consumed more and a greater breadth of invertebrate prey than breeding caracaras during the breeding season, January through April, in Florida.

\begin{tabular}{lcc}
\hline \multicolumn{1}{c}{ MEASURE OF DIET } & $\begin{array}{c}\text { BREEDING } \\
\text { CARACARAS }\end{array}$ & $\begin{array}{c}\text { NONBREEDING } \\
\text { CARAGARAS }\end{array}$ \\
\hline Number of pellets & 120 & 100 \\
Number of families & 24 & 28 \\
Number of genera & 49 & 64 \\
Family FNBst & 0.22 & 0.15 \\
Genus FNBst & 0.17 & 0.24 \\
$\quad \begin{array}{l}\text { Total invertebrate prey } \\
\quad \text { items }\end{array}$ & 929 & 1073 \\
Proportion Coleoptera & 0.65 & 0.85 \\
$\begin{array}{l}\text { Mean number of } \\
\text { invertebrates/pellet }( \pm \mathrm{SE})\end{array}$ & $7.7 \pm 1.7$ & $10.73 \pm 0.77$ \\
$\quad$ Total prey types & 58 & 77 \\
\hline
\end{tabular}

Over $75 \%$ of all pellets had matrix material containing $>25 \%$ plant material, primarily pieces of grass. In addition to containing more invertebrates per pellet, pellets of nonbreeders also contained higher percentages of plant material, overall, than pellets from breeders. Pellets containing 75-100\% plants in the matrix material contained more invertebrates than pellets with $0-25 \%$ plant material (breeders: $11.74 \pm 4.58$ vs. $5.51 \pm 1.54$ invertebrates per pellet, $t=-1.29, P=0.20$; nonbreeders: 12.46 \pm 1.11 vs. $9.08 \pm 1.57$ invertebrates per pellet, $t=$ $-1.76, P=0.08$, Fig. 2).

\section{Discussion}

During January through April in Florida, nonbreeding caracaras apparently consume a greater diversity and larger numbers of invertebrates, particularly from grassland habitats and carrion, than breeding caracaras, suggesting differential use of food resources or habitats during the breeding season by these groups. Travaini et al. (2001) reported that nonbreeding Southern Caracaras (C. plancus) during the breeding season in northwest Patagonia fed mostly on arthropods and carrion and generally consumed more arthropods than breeding adults. They attributed this difference to intraspecific competition in which immature birds are displaced to less-profitable prey by adult breeding birds (Travaini et al. 1998, 2001).

Several mechanisms have been proposed to explain differences in prey choice, feeding strategies, and feeding locations used by different individuals within a population, and these mechanisms, acting singly or together, may influence social structure (Partridge and Green 1985). First, food resources may be distributed in patches throughout the environment where different feeding strategies are ap-

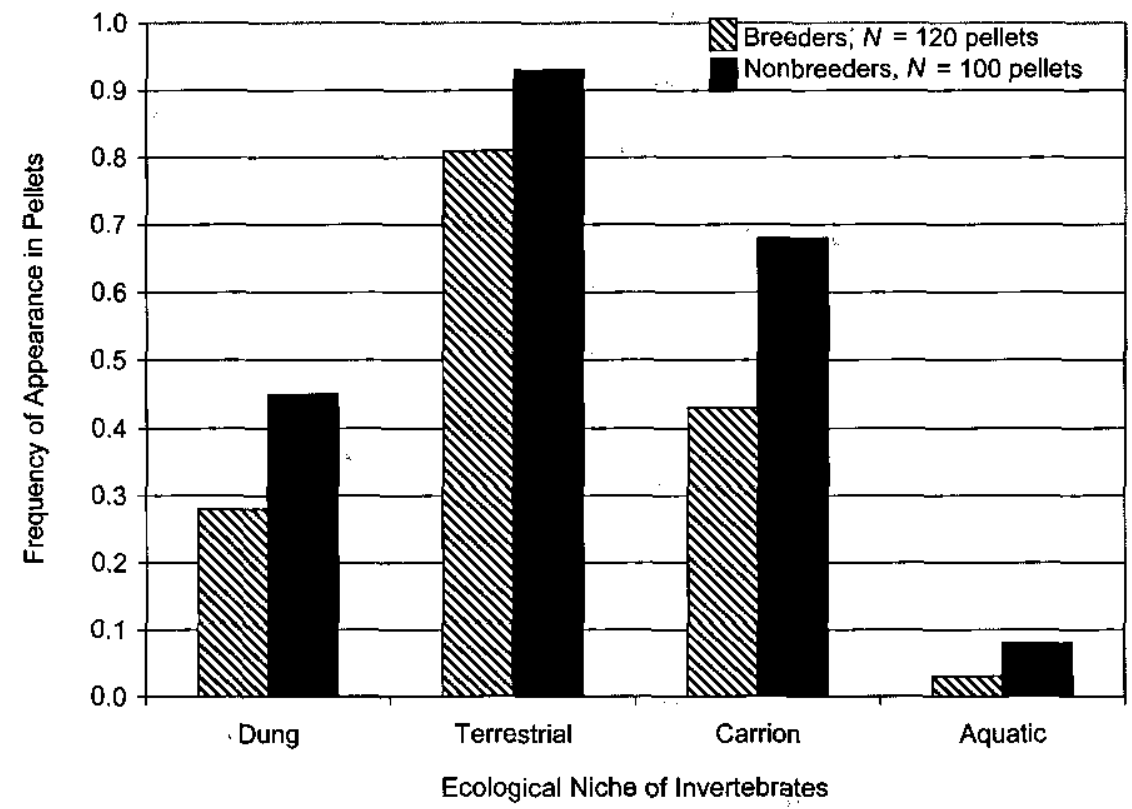

Figure 1. Invertebrates from all ecological niches occurred more frequently in pellets of nonbreeding caracaras ( $\mathrm{Ca}$ racara cheriway) in Florida, during the breeding season, January through April. 


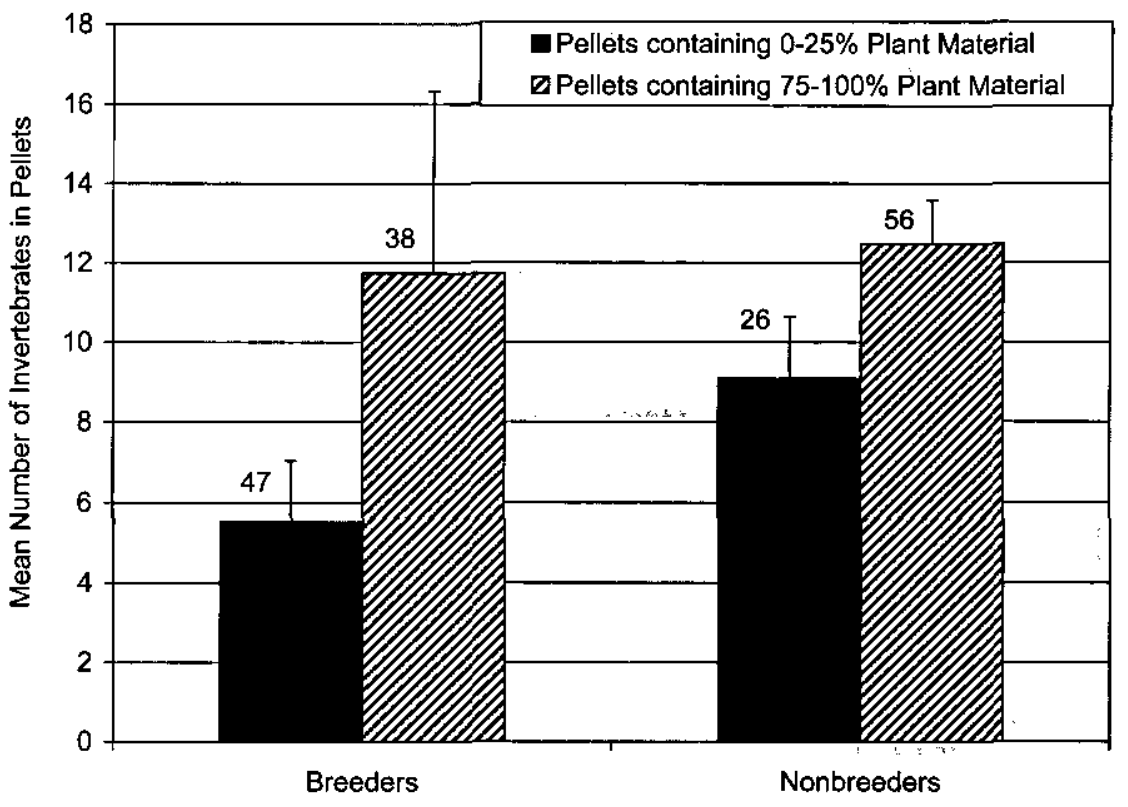

Caracara Breeding Status

Figure 2. Pellets from both breeding and nonbreeding caracaras that contained more plant material generally also contained more invertebrates. Number of pellets in each category is shown above each bar.

propriate. Individuals within a population typically distribute themselves according to differences in habitat quality, with younger or subordinate individuals occupying poorer habitat (Fretwell and Lucas 1970). Second, use of different habitats and prey choice may reflect differences in individual phenotypes, for example, age or sex. Young animals typically differ from adults in their feeding skills and may have different nutritional requirements from adults (Davies and Green 1976, Greig et al. 1983). Finally, behavior of an individual may depend on behavior of other individuals. Younger birds are often poorer competitors and may be actively excluded from the best habitats or more-profitable prey by adult breeding birds (Goss-Custard and Durrell 1983, Wallace and Temple 1987, Sol et al. 2000). Particularly in territorial species and at high population densities, occupancy of poor feeding areas may increase as individuals of low competitive ability are forced out of the better areas (Ens and GossCustard 1984).

In Florida, breeding pairs of northern Crested Caracaras nest primarily in pasture and grasslands interspersed with wetlands and some agriculture and are highly territorial (Morrison and Humphrey 2001). As with other raptors, breeding adult caraca- ras primarily feed nestlings larger-sized vertebrate prey (Morrison and Pias 2006), thus reducing energetic expenditure necessary to feed nestlings ( $\mathrm{Ru}-$ dolph 1982, Masman et al. 1986). Fewer invertebrates in the adults' breeding season diet may reflect reduced reliance by adults on arthropods or differential use of habitats during this period as they focus on larger prey.

Nonbreeding caracaras typically occur year-round in groups, at much higher densities than breeding pairs. Apparent differences in the invertebrate component of the diet of breeding and nonbreeding caracaras may be simply due to the fact that nonbreeders do not have the higher energy requirements of reproduction, and, therefore, do not need to be as selective in prey choice. Alternatively, ingestion of more invertebrates by nonbreeders may be a consequence of competition for more profitable food resources as suggested by Travaini et al. (2001). Field observations in Florida indicate that territorial adults can exclude young birds from their breeding areas ( $\mathrm{J}$. Dwyer unpubl. data) and thus, presumably, from favored foraging habitats. Morrison and Pias (2006) indicated the importance of wetland habitats to breeding pairs of caracaras based on large numbers of wetland-dependent prey 
delivered to nestlings. If pairs of breeding adults exclude conspecifics from important food resources or foraging habitats, diet differences may reflect social structure within this population. Nonbreeders may hunt arthropods or rely on carrion by necessity, especially if flocks of nonbreeders occur in suboptimal habitat in which other prey are less abundant or available. Rizzo et al. (1993) and Itămies and Korpimäki (1987) found that insects became important in the diet of kestrels (Falco tinnunculus) only in poor prey years or when typical prey, i.e., small mammals, were less available.

Although our analysis did not allow for evaluating diet differences among years for breeding pairs, similarity in the relative frequencies of invertebrates from different ecological niches both in the pellets and in the overall diet of breeding pairs suggested that any differences would be minimal. Most invertebrates in pellets of breeders and nonbreeders represented dung and terrestrial (grassland and pasture) habitats, and aquatic insects were rarely present (Fig. 1), suggesting caracaras obtained invertebrate prey mostly in grasslands, not wetlands. Because grassland and pasture habitats receive heavy and regular management annually (grazing, mowing, burning), these habitats may vary less among years than do wetlands, which undergo seasonal changes in water levels. Thus, we would not expect interannual variation among wetlands to be reflected in the caracara's diet as indicated by pellets.

Plant material in pellets has been reported for Turkey Vultures (Cathartes aura; Paterson 1984, Coleman and Fraser 1987), Cinereous Vultures (Aegypius monachus; Hiraldo 1976), and California Condors (Gymnogyps califormianus; Koford 1966) although little explanation has been given. While small amounts of plant material in pellets might be attributable to accidental ingestion, pellets composed of $>50 \%$ vegetation suggest that the plants may have a specific function, perhaps in the pellet egestion process. Plant material may serve to facilitate regurgitation of nondigestible animal parts (Hiraldo 1976) or may assuage effects of toxic substances ingested with some of the arthropods consumed (Morrison et al. 2007). Our discovery that, overall, pellets of nonbreeders contained more plant material and more invertebrates per pellet may lend support to the latter hypothesis.

Our findings suggest hypotheses regarding the possible role of intraspecific competition in the use of particular habitats and food resources by breeding and nonbreeding caracaras in Florida and on the role of plants in the caracara's diet. However, these hypotheses require further testing. Future studies should focus on feeding behaviors and use of resources by these different age groups both during and outside the breeding season. Conservation directives for Florida's caracaras currently focus on protecting nest sites and foraging habitat within breeding areas. If nonbreeding individuals require additional foraging areas, identification and inclusion of these sites will also be important for development of recovery plans for this population. Finally, it would be interesting to know the importance of arthropods and other invertebrates in the diet of both the Crested Caracara and Southern Caracara throughout their respective ranges, for all age groups and during all seasons.

\section{ACKNOWLEDGMENTS}

We thank L. Wang and S. Sullivan for assistance with pellet dissection. The manuscript was improved by comments from J. Dwyer, J. Donázar, and an anonymous reviewer. This manuscript is contribution \#105 of the MacArthur Agro-Ecology Research Center.

\section{LITERATURE CITED}

BaRRows, C.W. 1987. Diet shifts in breeding and nonbreeding Spotted Owls. J. Raptor Res. 21:95-97.

BEESTON, R., D. Baines, AND M. RichaRDSON. 2005. Seasonal and between-sex differences in the diet of Black Grouse Tetrao tetrix. Bird Study 52:276-281.

BUG GUIDE. 2007. Identification, images, and information for insects, spiders and their kin for the United States and Canada. Iowa State Univ., Ames, IA U.S.A., http:// bugguide.net/node/view/15740 (last accessed 20 July 2006).

Coleman, J.S. and J.D. Fraser. 1987. Food habits of Black and Turkey vultures in Pennsylvania and Maryland. $J$. Wildl. Manage. 51:733-739.

COLWELL, R.K. AND D.F. FUTUYMA. 1971. On the measurement of niche breadth and overlap. Ecology 52:567-576.

DAUBENMIRE, R. 1959. A canopy coverage method of vegetation analysis. Northwest Sci. 33:43-64.

DAVIES, N.B. AND R.E. GREEN. 1976. The development and ecological significance of feeding techniques in the reed warbler (Acrocephalus scirpaceus). Anim. Behav. 24:213-229.

DILLON, E.S. AND L.S. DILLON. 1972. A manual of common beetles of eastern North America, Vols. 1 and 2. Dover Publications Inc., New York Gity, NY U.S.A.

Dove, C.J. AND R.C. Banks. 1999. A taxonomic study of Crested Caracaras (Falconidae). Wilson Bull. 111:330-339.

ENS, B.J. AND J.D. GOSS-CUSTARD. 1984. Interference among oystercatchers, Haematopus ostralegus, feeding on mussels, Mytilus edulis, on the Exe estuary. J. Anim. Ecol. 53:217-231. 
FRETWELL, S.D. AND H.L. LUCAS, JR. 1970. On territorial behavior and other factors influencing habitat distribution in birds I: theoretical development. Acta Biotheor. 19:16-36.

Goss-Custard, J.D. AND S.E. DURRELl. '1983. Individual and age differences in the feeding ecology of oystercatchers Haematopus ostralegus wintering on the Exe estuary, Devon. Ibis 125:155-171.

Greig, S.A., J.C. Coulson, And P. Monaghan. 1983. Agerelated differences in foraging success in the Herring Gull (Larus argentatus). Anim. Behav. 31:1237-1243.

HIRALDO, F. 1976. Diet of the Black Vulture (Aegypius mon. achus) in the Iberian peninsula. Doñana Acta Vertebrata 3:19-31.

HoGSTAD, O. 1991. The effect of social dominance on foraging by the three-toed woodpecker Picoides tridactylus. Ibis 133:271-276.

ITÃMIES, J. AND E. KoRPIMĂKI. 1987. Insect food of the kestrel, Falco tinnunculus, during breeding in western Finland. Aquilo Ser. Zool. 25:21-31.

Koford, R. 1966. The California Condor. Natl. Audubon Soc. Res. Rep. 4:1-154.

LAYNE, J.N., F.E. LOHRER, AND E. WINEGARNER. 1977. Birds and mammal predators of the Cattle Egret in Florida. Fla. Field Nat. 5:1-4.

LeVINS, R. 1968. Evolution in changing environments. Princeton Univ. Press, Princeton, NJ U.S.A.

MARTI, C.D. 1987. Raptor food habits studies. Pages 67-80 in B.A. Giron Pendleton, B.A. Millsap, K.W. Cline, and D.M. Bird [EDS.], Raptor management techniques manual. Natl. Wildl. Fed, Washington, DC U.S.A.

Masman, D., M. Gordij, S. DaAn, AND C. Dijkstra. 1986. Ecological energetics of the kestrel: field estimates of energy intake throughout the year. Ardea 74:24-39.

MORRISON, J.L. 1996. Crested Caracara (Caracara plancus). In A. Poole and F. Gill [EDs.], The birds of North America, No. 249. The Academy of Natural Sciences, Philadelphia, PA and The American Ornithologists' Union, Washington, DC U.S.A.

- J. Abrams, M. Deyrup, T. Eisner, ANd M. MCMiL LIAN. 2007. Noxious menu: chemically protected insects in the diet of the Crested Caracara. Southeast. Nat. $6: 1-14$.

AND S.R. HuMPHREY. 2001. Conservation value of private lands for Crested Caracaras in Florida. Conserv. Biol. 15:675-684.

AND K.E. PLAS. 2006. Assessing the vertebrate component of the diet of Florida's Crested Caracaras ( $\mathrm{Ca}$ racara cheriway). Fla. Sci. 69:36-43.

NewTon, I. 1979. Population ecology of raptors. T. and A.D. Poyser, London, U.K.
Partridge, L. ANd P. Green. 1985. Intraspecific feeding specializations and population dynamics. Pages 207-226 in R.M. Sibly and R.H. Smith [EDS.], Behavioural Ecology. Blackwell Scientific Publications, Oxford, U.K.

PATERSON, R.L., JR. 1984. High incidence of plant material and small mammals in the autumn diet of Turkey Vultures in Virginia. Wilson Bull. 96:467-469.

PETERS, W.D. AND T.C. GRUBB. 1983. An experimental analysis of sex-specific foraging in the Downy Woodpecker, Picoides pubescens. Ecology 64:1437-1443.

Planka, E.R. 1973. The structure of lizard communities. Annu. Rev. Ecol. Syst. 4:53-74.

RICHMOND, A.N. 1976. Feeding of nestlings by the caracara in Costa Rica. Wilson Bull. 88:667.

Rizzo, M.C., M. Migliore, AND B. Massa. 1993. Insects, small mammals and breeding performance of farmland populations of the common kestrel (Falco tinnunculus) in Italy. Pages 11-18 in M.K. Nicholls and R. Clarke [EDS.], Biology and conservation of small falcons: proceedings of the 1991 Hawk and Owl Trust conference. The Hawk and Owl Trust, London, U.K.

RODRíguez-Estrella, R. AND L.B. RIVERA-RodríguEZ. 1997. Crested Caracara food habits in the cape region of Baja California, Mexico. J. Raptor Res. 31:228-233.

RUDOLPH, S.G. 1982. Foraging strategies of American Kestrels during breeding. Ecology 63:1268-1276.

Sol, D., D.M. SANTos, AND M. CuRAdrado. 2000. Age-related feeding site selection in urban pigeons (Columba livia): experimental evidence of the competition hypothesis. Can. J. Zool. 78:144-149.

Travaini, A., J.A. Donázar, O. Ceballos, and F. Hiraldo. 2001. Food habits of the Crested Caracara (Caracara plancus) in the Andean Patagonia: the role of breeding constraints. J. Arid Environ. 48:211-219.

—, - A. Rodríguez, O. Ceballos, M. Funes, AND F. Hiraldo. 1998. Use of European hare (Lopus europaeus) carcasses by an avian scavenging assemblage in Patagonia. J. Zool. 246:175-181.

VarGas, R.J., M.S. Bó, ANd M. Favero. 2007. Diet of the Southern Caracara (Caracara plancus) in Mar Chiquita Reserve, Southern Argentina. J. Raptor Res. 41:113-121.

Wallace, M.P. AND S.A. Temple. 1987. Competitive interactions within and between species in a guild of avian scavengers. Auk 104:290-295.

WhitACRE, D., D. UkRAiN, AND G. FALXA. 1982. Notes on the hunting behavior and diet of the Crested Caracara in northeastern Chiapas and Tabasco, Mexico. Wilson Bull. 94:565-566.

WHITE, R.E. 1983. A field guide to beetles of North America. Houghton Mifflin Company, Boston, MA U.S.A.

Received 1 August 2007; accepted 7 November 2007 


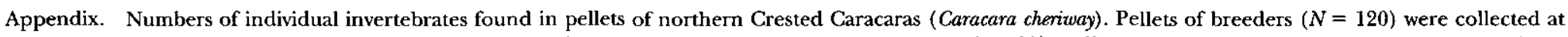

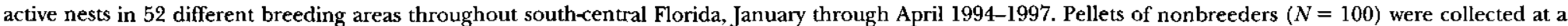
communal roost on the MacArthur Agro-ecology Research Center, Lake Placid, FL, January through April 1999.

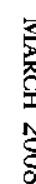

\begin{tabular}{|c|c|c|c|c|c|c|c|c|c|}
\hline \multirow[b]{2}{*}{ ECOLOGICAL. NICHE } & \multirow[b]{2}{*}{ ORDER } & \multirow[b]{2}{*}{ FAMlLY } & \multirow[b]{2}{*}{ SPECIES } & \multirow[b]{2}{*}{ NUMBER } & \multicolumn{2}{|c|}{ BREEDERS } & \multirow[b]{2}{*}{ Number } & \multicolumn{2}{|c|}{ NONBREEDERS } \\
\hline & & & & & $\begin{array}{c}\text { PERCENTAGe } \\
\text { OF TOTAL } \\
\text { PREY ITEMS }\end{array}$ & $\begin{array}{c}\text { FrEQuENCY of } \\
\text { OCCURRENCE } \\
\text { IN PELLETS }\end{array}$ & & $\begin{array}{c}\text { PERCENTAGEOF } \\
\text { TOTAL PREY } \\
\text { ITEMS }\end{array}$ & $\begin{array}{c}\text { FREQUENCYOF } \\
\text { OCCURRENCE } \\
\text { IN PELLETS }\end{array}$ \\
\hline \multirow[t]{9}{*}{ Dung } & \multirow[t]{9}{*}{ Coleoptera } & \multirow[t]{9}{*}{ Scarabaeidae } & Onthophagus gazella & 72 & 7.8 & 6.7 & 21 & 2.0 & 12.0 \\
\hline & & & O. hecate blatchleyi & 28 & 3.0 & 14.3 & 44 & 4.1 & 29.0 \\
\hline & & & O. tuberculifrons & 7 & 0.8 & 0.8 & 0 & 0.0 & 0.0 \\
\hline & & & Aphodius pseudolividus & 2 & 0.2 & 1.7 & 10 & 0.9 & 5.0 \\
\hline & & & A. campestris & 4 & 0.4 & 2.5 & 0 & 0.0 & 0.0 \\
\hline & & & A. floridanus & 0 & 0.0 & 0.0 & 8 & 0.8 & 6.0 \\
\hline & & & Phanaeus vindex & 13 & 1.4 & 9.2 & 2 & 0.2 & 2.0 \\
\hline & & & Canthon vigilans & 1 & 0.1 & 0.8 & 0 & 0.0 & 0.0 \\
\hline & & & Boreocanthon depressipennis & 0 & 0.0 & 0.0 & 2 & 0.2 & 2.0 \\
\hline \multirow{19}{*}{$\begin{array}{l}\text { Ground-dwelling } \\
\text { grassland or } \\
\text { woodland }\end{array}$} & \multirow[t]{19}{*}{ Coleoptera } & \multirow[t]{11}{*}{ Scarabaeidae } & Dyscinetus morator & 63 & 6.8 & 30.3 & 143 & 13.3 & 46.0 \\
\hline & & & Euetheola humilis & 19 & 2.1 & 5.9 & 85 & 8.0 & 27.0 \\
\hline & & & D. morator OR E. humilis & 0 & 0.0 & 0.0 & 73 & 6.8 & 21.0 \\
\hline & & & Euphoria sepulcralis & 4 & 0.4 & 1.7 & 0 & 0.0 & 0.0 \\
\hline & & & Phyllophaga latifroms & 0 & 0.0 & 0.0 & 20 & 1.9 & 1.0 \\
\hline & & & $P$. spp. & 4 & 0.4 & 2.5 & 0 & 0.0 & 0.0 \\
\hline & & & Anomala marginata & 0 & 0.0 & 0.0 & 1 & 0.1 & 1.0 \\
\hline & & & Ataenius alternatus & 0 & 0.0 & 0.0 & 3 & 0.3 & 3.0 \\
\hline & & & A. fattigi & 0 & 0.0 & 0.0 & 8 & 0.8 & 7.0 \\
\hline & & & A. spp. & 0 & 0.0 & 0.0 & 12 & 1.1 & 5.0 \\
\hline & & & Strategus antaeus & 2 & 0.2 & 0.8 & 0 & 0.0 & 0.0 \\
\hline & & \multirow[t]{8}{*}{ Carabidae } & Calosoma sayi & 1 & 0.1 & 0.8 & 2 & 0.2 & 2.0 \\
\hline & & & Cyclotrachelus faber & 3 & 0.3 & 1.7 & 14 & 1.3 & 2.0 \\
\hline & & & C. spp. & 0 & 0.0 & 0.0 & 2 & 0.2 & 2.0 \\
\hline & & & Scarites subterraneus & 3 & 0.3 & 2.5 & 10 & 0.9 & 9.0 \\
\hline & & & S. quadriceps & 3 & 0.3 & 2.5 & 2 & 0.2 & 2.0 \\
\hline & & & Pasimachus sublaevis & 14 & 1.5 & 9.2 & 2 & 0.2 & 2.0 \\
\hline & & & Amblygnathus spp. & 0 & 0.0 & 0.0 & 1 & 0.1 & 1.0 \\
\hline & & & Selenophorus palliatus & 0 & 0.0 & 0.0 & 1 & 0.1 & 1.0 \\
\hline
\end{tabular}




\begin{tabular}{|c|c|c|c|c|c|c|c|c|c|}
\hline \multirow[b]{2}{*}{ ECOLOGICAL NichE } & \multirow[b]{2}{*}{ ORDER } & \multirow[b]{2}{*}{ FAMILY } & \multirow[b]{2}{*}{ SPECIES } & \multirow[b]{2}{*}{ NUMBER } & \multicolumn{2}{|c|}{ BREEDERS } & \multirow[b]{2}{*}{ NUMBER } & \multicolumn{2}{|c|}{ NONBREEDERS } \\
\hline & & & & & $\begin{array}{c}\text { PERCENTAGE } \\
\text { OF TOTAL } \\
\text { PREY IteMS }\end{array}$ & $\begin{array}{c}\text { FREQUENCY OF } \\
\text { OCCURRENCE } \\
\text { IN PELLETS }\end{array}$ & & $\begin{array}{c}\text { Percentageof } \\
\text { TotaL Prex } \\
\text { ITEMS }\end{array}$ & $\begin{array}{c}\text { FrEQUENCY OF } \\
\text { OCCURRENCE } \\
\text { IN PELLETS }\end{array}$ \\
\hline & & Curculionidae & Pachnaeus litus & 0 & 0.0 & 0.0 & 3 & 0.3 & 2.0 \\
\hline & & & Sphenophorus venatus & 3 & 0.3 & 2.5 & 50 & 4.72 & 25.0 \\
\hline & & & S. necydaloides & 0 & 0.0 & 0.0 & 8 & 0.8 & 4.0 \\
\hline & & & S. cariosus & 3 & 0.3 & 2.52 & 2 & 0.2 & 2.0 \\
\hline & & & S. inaequalis & 2 & 0.2 & 1.7 & 1 & 0.1 & 1.0 \\
\hline & & & S. chittendeni & 0 & 0.0 & 0.0 & 1 & 0.1 & 1.0 \\
\hline & & & S. spp. & 7 & 0.8 & 5.9 & 9 & 0.9 & 5.0 \\
\hline & & & Rhynchophorus cruentatus & 7 & 0.8 & 2.5 & 0 & 0.0 & 0.0 \\
\hline & & & Tyloderima spp. & 1 & 0.1 & 0.8 & 0 & 0.0 & 0.0 \\
\hline & & Elateridae & Blauta cribraria & 0 & 0.0 & 0.0 & 3 & 0.3 & 3.0 \\
\hline & & & Neotrichophorus carolinensis & 0 & 0.0 & 0.0 & 1 & 0.1 & 1.0 \\
\hline & & & Heteroderes amplicollis & 1 & 0.1 & 0.8 & 1 & 0.1 & 1.0 \\
\hline & & & Conoderus bellus & 2 & 0.2 & 0.8 & 2 & 0.2 & 1.0 \\
\hline & & & Melanotus americanus & 3 & 0.3 & 0.8 & 5 & 0.5 & 2.0 \\
\hline & & & Unid. genus & 4 & 0.4 & 3.4 & 0 & 0.0 & 0.0 \\
\hline & & Tenebrionidae & Opatrinus minimus & 9 & 0.9 & 5.9 & 24 & 2.3 & 15.0 \\
\hline & & & Lobopoda erythrocnemis & 0 & 0.0 & 0.0 & 2 & 0.2 & 2.0 \\
\hline & & & Bothrotes canaliculatus & 0 & 0.0 & 0.0 & 2 & 0.2 & 1.0 \\
\hline & & & Alobates pennsylvanicus & 0 & 0.0 & 0.0 & 1 & 0.1 & 1.0 \\
\hline & & Unid. family & & 25 & 2.7 & 10.9 & 6 & 0.6 & 6.0 \\
\hline & Heteroptera & Pentatomidae & Acrosternum pennsylvanicum & 1 & 0.1 & 0.8 & 1 & 0.1 & 1.0 \\
\hline & Dermaptera & Forficulidae & Doru taeniatum & 0 & 0.0 & 0.0 & 1 & 0.1 & 1.0 \\
\hline & & Labiduridae & Labidura riparia & 1 & 0.1 & 0.8 & 1 & 0.1 & 1.0 \\
\hline & & Carcinophoridae & Anisolabis maritima & 0 & 0.0 & 0.0 & 1 & 0.1 & 1.0 \\
\hline & & & Euborellia annulipes & 3 & 0.3 & 0.8 & 8 & 0.8 & 7.0 \\
\hline & & Labiidae & Unid. genus & 0 & 0.0 & 0.0 & 1 & 0.1 & 1.0 \\
\hline & & Coreidae & Leptoglossus spp. & 1 & 0.1 & 0.8 & 0 & 0.0 & 0.0 \\
\hline & Orthoptera & Acrididae & Melanoplus tequestae & 1 & 0.1 & 0.8 & 0 & 0.0 & 0.0 \\
\hline & & & M. spp. & 0 & 0.0 & 0.0 & 4 & 0.4 & 2.0 \\
\hline & & & Schistocerca spp. & 0 & 0.0 & 0.0 & 1 & 0.1 & 1.0 \\
\hline & & & Unid. genus & 21 & 2.3 & 14.3 & 22 & 2.1 & 18.0 \\
\hline
\end{tabular}




\begin{tabular}{|c|c|c|c|c|c|c|c|c|c|}
\hline \multirow[b]{2}{*}{ ECOLOGICAL NICHE } & \multirow[b]{2}{*}{ ORDER } & \multirow[b]{2}{*}{ FAMILY } & \multirow[b]{2}{*}{ SPECIES } & \multirow[b]{2}{*}{ NUMBER } & \multicolumn{2}{|c|}{ BREEDERS } & \multirow[b]{2}{*}{ NUMBER } & \multicolumn{2}{|c|}{ NONBREEDERS } \\
\hline & & & & & $\begin{array}{l}\text { Percentage } \\
\text { OF Total } \\
\text { Prey ItEms }\end{array}$ & $\begin{array}{c}\text { FrEQUENCY OF } \\
\text { OCCURRENCE } \\
\text { IN PELletS }\end{array}$ & & $\begin{array}{c}\text { PERCENTAGEOF } \\
\text { TOTAL PREY } \\
\text { ITEMS }\end{array}$ & $\begin{array}{c}\text { FREQUENCY OF } \\
\text { OCCURRENCE } \\
\text { IN PELLETS }\end{array}$ \\
\hline & & Gryllidae & Gryllus assimilis & 0 & 0.0 & 0.0 & 4 & 0.4 & 1.0 \\
\hline & & & $G$ spp. & 2 & 0.2 & 1.7 & 0 & 0.0 & 0.0 \\
\hline & & & Unid. genus & 0 & 0.0 & 0.0 & 7 & 0.7 & 6.0 \\
\hline & & Gryllotalpidae & Scapteriscus vicinus & 35 & 3.8 & 16.8 & 4 & 0.4 & 4.0 \\
\hline & & & Neocurtilla hexadactyla & 9 & 1.0 & 5.0 & 1 & 0.1 & 1.0 \\
\hline & & & Unid. genus & 25 & 2.7 & 20.2 & 22 & 2.1 & 21.0 \\
\hline & & Tettigoniidae & Neoconocephalus triops & 0 & 0.0 & 0.0 & 1 & 0.1 & 1.0 \\
\hline & & Tetrigidae & Unid. genus & 0 & 0.0 & 0.0 & 6 & 0.6 & 2.0 \\
\hline & Araneae & Salticidae & Phidippus spp. & 1 & 0.1 & 0.8 & 0 & 0.0 & 0.0 \\
\hline & & Lycosidae & Unid. genus & 44 & 4.7 & 28.6 & 45 & 4.3 & 35.0 \\
\hline & & Unid. family & Unid. genus & 1 & 0.1 & 0.8 & 0 & 0.0 & 0.0 \\
\hline \multirow[t]{18}{*}{ Carrion } & Coleoptera & Silphidae & Necrodes surinamensis & 198 & 21.3 & 24.4 & 85 & 8.0 & 36.0 \\
\hline & & & Oiceoptoma inaequalis & 33 & 3.5 & 10.1 & 4 & 0.4 & 3.0 \\
\hline & & & $O$. spp. & 0 & 0.0 & 0.0 & 1 & 0.1 & 1.0 \\
\hline & & & Nicrophorus spp. & 1 & 0.1 & 0.8 & 3 & 0.3 & 3.0 \\
\hline & & Dermistidae & Dermestes spp. & 24 & 2.6 & 13.4 & 103 & 9.7 & 37.0 \\
\hline & & Histeridae & Hister abbreviatus & 13 & 1.4 & 5.0 & 33 & 3.1 & 16.0 \\
\hline & & & Saprinus pennsylvanicus & 0 & 0.0 & 0.0 & 5 & 0.5 & 4.0 \\
\hline & & & Euspilotus assimilis & 12 & 1.3 & 5.0 & 67 & 6.3 & 23.0 \\
\hline & & Trogidae & Omorgus suberosus & 3 & 0.3 & 2.5 & 0 & 0.0 & 0.0 \\
\hline & & & O. prunctatus & 1 & 0.1 & 0.8 & 0 & 0.0 & 0.0 \\
\hline & & $\therefore$ & O. spp. & 0 & 0.0 & 0.0 & 7 & 0.7 & 5.0 \\
\hline & & & Trox spp. & 2 & 0.2 & 0.8 & 0 & 0.0 & 0.0 \\
\hline & & & Unid. genus & 1 & 0.1 & 0.8 & 0 & 0.0 & 0.0 \\
\hline & & Cleridae & Necrobia rufipes & 0 & 0.0 & 0.0 & 3 & 0.3 & 3.0 \\
\hline & & Nitidulidae & Nitidula ziczac & 0 & 0.0 & 0.0 & 2 & 0.2 & 2.0 \\
\hline & & Staphylinidae & Creophilus maxillosus & 2 & 0.2 & 1.7 & 2 & 0.2 & 1.0 \\
\hline & Diptera & Stratiomyidae & Larvae & 0 & 0.0 & 0.0 & 24 & 2.3 & 8.0 \\
\hline & & Calliphoridae & Cochliomyia macellaria & 179 & 19.3 & 4.2 & 0 & 0.0 & 0.0 \\
\hline \multirow[t]{8}{*}{ Aquatic } & Coleoptera & Hydrophilidae & Enochrus perplexus & 0 & 0.0 & 0.0 & 1 & 0.1 & 1.0 \\
\hline & & & Tropisternus lateralis & 1 & 0.1 & 0.8 & 1 & 0.1 & 1.0 \\
\hline & & & T. mexicanus & 1 & 0.1 & 0.8 & 2 & 0.2 & 2.0 \\
\hline & & & Phaenonotum minor & 0 & 0.0 & 0.0 & 1 & 0.1 & 1.0 \\
\hline & & Noteridae & Hydrocanthus regius & 0 & 0.0 & 0.0 & 1 & 0.1 & 1.0 \\
\hline & Hemiptera & Corixidae & Unid. genus & 0 & 0.0 & 0.0 & 1 & 0.1 & 1.0 \\
\hline & & Belostomatidae & Belostoma testaceum & 0 & 0.0 & 0.0 & 3 & 0.3 & 3.0 \\
\hline & Decapoda & Cambaridae & Unid. genus & 2 & 0.2 & 1.7 & 0 & 0.0 & 0.0 \\
\hline
\end{tabular}

